\title{
PATHOLOGICAL STUDIES ON SOME EQUINE SKIN TUMORS
}

\author{
AL-KLAMAWEY, NAGLAA M. ${ }^{1}$, GEHAN G.SHEHAB ${ }^{1}$, \\ M.B. EL-BEGAWY ${ }^{2}$ AND A.A. SHALABY ${ }^{2}$ \\ 1 Animal Health Research Institute, ARC, Ministry of Agriculture, Dokki - Giza \\ 2 Faculty of Veterinary Medicine, Beni - Suef University
}

(Manuscript received 19 April 2011)

\begin{abstract}
The present study was carried out to give spotlight on different types of cutaneous neoplasms in equines in Egypt. For this purpose, sixty-three cases of equine cutaneous neoplasms were collected from different locations in Egypt (Zahraa farm, Giza Zoo, Military Vet. Hospital, Brooke Hospital and different Vet. Clinics). Surgical removal of these skin tumors was carried out and followed by preparation of tissue samples for pathological investigation.

The pathological examination showed that the most predominant types of equine skin tumors were sarcoids which represented $58.73 \%$ of all equine cutaneous tumors. The general cutaneous changes in all types of sarcoids were the intensified dermal proliferation.

The next type was fibroma which was seen at a percent of $12.69 \%$ in both soft and hard forms with characteristic fibrous connective tissue proliferation in association with collagen production in variable amounts. The vascular tumor was detected at a high percentage $(11.11 \%)$, microscopic examination showed high degrees of vascular channel proliferations of different sizes. The detected types were capillary and mixed hemangiomas.

Papilloma at a percent of $7.9 \%$ was also observed and showed hyperkeratosis, finger-like projections, marked hyperplasia of the epidermis and intracellular keratohyaline material. Squamous cell carcinoma was detected at $4.75 \%$ in two types: well-differentiated and anaplastic forms. Regarding melanoma, it was also seen in two forms depending on the melanocytes and melanophages location in the dermis.
\end{abstract}

\section{INTRODUCTION}

Skin affections in equines represent an economic importance for both the racing industry and peasants of the developing countries. Losses due to mortality, loss of condition and the appearance of the animal must be taken in consideration.

A variety of skin tumors had been reported. The incidence is somewhat variable depending on the geographical location and type of equines surveyed. Rooney and Robertson (1996) recorded the incidence of cutaneous neoplasms in equines as $60 \%$ sarcoids, $10 \%$ squamous cell carcinoma, $21 \%$ fibroma, $1.0 \%$ papilloma, $4 \%$ hemangiomas, $3 \%$ melanoma and $1.0 \%$ adenoma. 
Sarcoids were considered one of the most common and worldwide detected types of equine skin tumors (Goldschmidt and Hendrick, 2002). Although sarcoid was defined as a benign tumor, but, it is sometimes showing an aggressive growth or even recurrent (Ragland, et. al., 1970). Sarcoids may occur anywhere on the body, especially on the head, legs and ventral trunk (Scott, 1988). Pathologically, 5 types of sacroids were recorded (Martens, 2000).

Therefore, the current study was carried out to clarify the different types of equine cutaneous neoplasms and trying to give a proportional percentage to each type according to the frequency of their occurrence.

\section{MATERIALS AND METHODS}

A survey on cutaneous tumors in equines of different ages and sexes was carried out at different locations in Egypt. A total of 63 tissue samples were collected from 15 horses and 48 donkeys (1-6 years old) by surgical interference as following : Operated animals were deeply anesthetized by intravenous injection of chloral hydrate $10 \%$ at a dose rate of $5 \mathrm{~g} / 50 \mathrm{Kg}$ body weight. The animals to be operated were prepared for aseptic surgery. The tumor was carefully dissected out from the surrounding tissues. Care was taken to remove all the tumor tissue. The gross examination of the collected cutaneous tumors was done and tissue specimens from each lesion was taken and fixed in $10 \%$ neutral formalin, dehydrated in ethyl alcohol, cleared in xylene and embedded in paraffin. Sections of 4 - 5 microns thickness were obtained and stained by $H \& E$ for routine histopathological examination and by Masson's trichrome for fibrous connective tissue detection (Bancroft and Stevens, 1996).

\section{RESULTS}

On surveying cutaneous tumors in horses and donkeys in different localities, 63 specimens (15 horses and 48 donkeys) were examined by routine histopathological technique. The results revealed that 37 samples were sarcoids (6 horses and 31 donkeys), 8 fibromas ( 3 horses and 5 donkeys), 7 vascular tumors ( 3 horses and 4 donkeys), 5 papillomas ( 1 horse and 4 donkeys), 3 squamous cell carcinomas from donkeys and 3 melanomas ( 2 horses and 1 donkey) as shown in Table 1. 
Table 1. The incidence of cutaneous neoplasms in examined equines

\begin{tabular}{|c|c|c|c|c|c|c|}
\hline TYPE & Sarcoids & Fibroma & $\begin{array}{c}\text { Vascular } \\
\text { tumors }\end{array}$ & Papilloma & S.C.C. & Melanoma \\
\hline Number & 37 & 8 & 7 & 5 & 3 & 3 \\
\hline Percentage & $58.73 \%$ & $12.69 \%$ & $11.11 \%$ & $7.90 \%$ & $4.76 \%$ & $4.76 \%$ \\
\hline
\end{tabular}

\section{Gross examination}

\section{Sarcoids}

The obtained sarcoids were classified macroscopically and microscopically into 5 types : fibroblastic, verrucous, mixed, nodular and occult.

Fibroblastic sarcoids (16 cases, 3 horses and 13 donkeys) were detected on the fetlock joint ( 7 cases), on the knee ( 5 cases) and 4 on the hock joints. The gross appearance of the tumors revealed moderate to large fleshy mass of hump-like shape or folded, partially covered by hard or fine crusty deposits with ulcerate or hairless surface (Fig. 1a). Histologically, the tumors were characterized by partial to complete ulcerations of the epidermis, the remaining epithelial cells showed ballooning degeneration. The basement membrane sent long thin rete pegs of pseudoepitheliomatous hyperplasia into the dermal layer. Picket fence formation could also be recorded (Fig.2). The dermis showed proliferation of variable amounts of fibroblasts and collagen fibers (Fig.3).

Verrucous sarcoids (9 cases, one horse with tumor on the hock joint and 8 donkeys with 5 tumors on the hock and 3 on the stifle joints) were detected. The gross appearance showed nodular or circumscribed tumor masses with hard keratinized surface. Histologically, the epidermis appeared moderately hyperkeratotic. The basal cell layer was markedly proliferated, while, the basement membrane sent long thin rete pegs of pseudoepitheliomatous hyperplasia down into proliferated dermal fibroblasts. At the dermo-epidermal junction, the fibroblasts were perpendicular to the basement membrane forming 'picket fence' which is considered a characteristic feature for verrucous sarcoids (Fig.4). The dermis showed abundant collagen deposition intermixed with proliferated fibroblasts which contained rounded hyperchromatic nuclei.

Mixed sarcoids ( 7 cases, 2 horses with tumors on the fetlock joint and 5 donkeys with tumor masses on the cheeks) showed consistently hyperkeratosis. Macroscopically, the tumor appeared as nodules covered with fine black crusts. The cross section revealed white glassy appearance with gelatinous texture. Microscopically, the prickle cell layer showed focal or diffuse proliferation. Some parts 
of the epidermis sent very long thin rete pegs into the dermis with picket fence formation (Fig.5). In some areas, the epidermis was ulcerate with presence of necrosis, hemorrhage and inflammatory cell infiltration. The dermis contained capillary poor fibroblast proliferations of fusiform or spindle-shaped. They were forming whorls or interlacing bundles showing haphazard arrays.

Nodular sarcoids ( 3 cases located only in donkeys, one in the scrotum and 2 on the saddle area) were characterized macroscopically by presence of subcutaneous thickened mass under an intact skin. Histological picture revealed mild to moderate hyperkeratosis and parakeratosis. The rete pegs were few and short without ulceration of the epidermis. Bundles of collagen fibers were detected, especially, in the deeper layer of dermis (Fig.6). No 'picket fence' formation was detected in these types of sarcoids.

Occult sarcoids ( 2 cases on the shoulder area of donkeys) showed circular thickened cutaneous mass with central area of light pigmentation (Fig. 1b). Microscopic examination showed variable amounts of keratin ranged from mild to moderate hyperkeratosis, followed by a layer of focal proliferative prickle cells. The 'picket fence' pattern or cystic hair follicles were not detected (Fig.7). Wavy arrangements of proliferated fibroblasts in the superficial dermal layer were observed with spindle-shape elongated hyperchromatic nuclei.

\section{Fibromas}

Eight cases were recorded ( 5 in the limbs of 3 horses and 2 donkeys and 3 in the scrotum of donkeys). Fibromas were firm, well circumscribed movable nodules under an intact skin. Microscopically, fibromas were classified into: a) Soft fibroma (5 cases) which revealed that the fibroblasts were predominating on the expense of the collagen matrix. Most of the fibroblasts were spindle- or fusiform- shaped, and contained spindle - shaped or satellite hyperchromatic nuclei arranged in tight whorls or interlacing bundles with less amount of fine wavy arranged collagen bundles (Fig. 8). Mitotic figures were few.

b) Hard fibroma (3 cases) which showed that the fibrous material was predominating on the expense of cell bodies. The dermis was diffusely infiltrated by numerous thick interwoven bands of collagen which extended between skeletal muscle bundles or in form of fine wavy or thick compact bundles with few large vesicular nuclei at the periphery of the bundles (Fig. 9).

\section{Vascular Tumors}

Seven cases were obtained ( 5 on the carpal joints of 3 horses and 2 donkeys and 2 on the shoulder joints of donkeys). Macroscpically, the lesions appeared as solitary firm cutaneous masses with ulcerate surface with hemorrhagic cross section 
(Fig.10). Microscopic examination of the dermis showed benign and well differentiated lesions divided into 2 groups on the morphogenetic basis :

Group 1. (5 cases) included dermal multiple coalescing clusters of vascular spaces with small lumen (capillary haemangiomas). The vascular spaces were lined by single layer of flattened endothelial cells with substantial number of pericytes concentrically arranged around them and closely encircled by few to multiple concentric fusiform layers (Fig.11).

Group 2. (2 cases) included dermal lesions with features of both cavernous and capillary haemangiomas (mixed haemangiomas) which consisted of multiple foci of closely - packed convoluted small vessels lined by a single layer of well differentiated endothelial cells. Surrounding the endothelium, there were substantial numbers of pericytes concentrically arranged and closely encircled by layers of fusiform fibroblasts. Multiple interconnecting, moderately large blood channels lined by endothelial cells were frequently observed. These channels were supported by moderately thick collagenous septa (Fig.12).

\section{Papilloma}

Papillomas ( 5 cases, one horse and 4 donkeys) were detected on the upper lip as smooth, elevated, brownish - coloured pedunculated nodules with narrow points of attachment. Other lesions showed finger-like projections (Fig.13). Microscopic examination of the epidermis, showed features of full-developed papillomas. The epidermis was massively thickened with hyperplasia of the stratum cornium and spinosum. Rete pegs were interdigitated within the hyperplastic connective tissue of the dermal papillary layer. Clusters of epidermal cells with vacuolated or granular cytoplasms were observed specially in the stratum spinosum. The basal cell layer showed marked hyperplasia with mitotic activity (Fig.14). Acidophilic cytoplasmic granules of abnormal keratohyaline material were seen in some prickle cells (Fig. 15).

\section{Squamous cell carcinoma}

The lesions ( 3 donkey cases, one was detected at the root of the tail and 2 on the fetlock joint) appeared as fleshy mass with hemorrhagic ulcerate surface (Fig.16). Two pathological features were detected (well-differentiated and anaplastic forms of SCC) . In well- differentiated SCC (two cases) the lesions were characterized by hyperkeratosis, parakeratosis and acanthosis. Partial ulceration of the epidermis was associated with necrosis and severe inflammatory cell infiltrations. There were irregular cords of the epidermal cells invading the dermis in association with inflammatory cell infiltrations. The tumor cells resembled those of normal stratum spinosum. The formed keratin was arranged in whorls in the center of large 
polyhedral prickle cells, some nests showed an additional outer basal cell layer with few mitotic figures and variable amounts of melanin granules. In more advanced stage of bird nests formation, there were multiple whorls of keratin layers in the center of the nest, forming "pearls" (Fig.17).

The second pathological picture was anaplastic form of SCC (one case) which showed progressed features of SCC. The epidermis was severely ulcerate with multifocal areas of necrosis, hemorrhage and infiltrating neutrophils. The dermis was infiltrated by malignant keratinocyte forming irregular sheets and nests. The malignant kerationcytes showed frequent mitosis, the nuclei were pleomorphic and hyperchromatic (Fig.18). Some of the nests contained highly eosinophilic laminated keratin in different stages of formation (Fig. 19).The stroma among the infiltrated sheets and nests was dense and fibrous, as well as, infiltrated by inflammatory cells.

\section{Melanocytic tumors}

The lesions ( 3 cases, one on the thigh of a donkey and 2 under the tail of horses) appeared as black coloured masses of shiny appearance. Microscpically, there were 2 different forms of melanocytic tumors. Two cases showed dermal melanoma and one case showed anaplastic (malignant) melanoma. Dermal melanomas were characterized by the presence of heavily pigmented dendritic shape melanocytes arranged in strands or nests embedded in connective tissue stroma. Melanin content in most of the tumor cells masked the cytoplasmic and nuclear details. The cells represented a mixture of melanocytes and melanophages (Fig.20). Concerning malignant melanoma, it showed ulceration of the overlying epidermis. The dermoepidermal junction and the superficial dermal layer had few numbers of melanocytes with haemorrhages. The deep dermal layer was heavily invaded by sheets or nests of ovoid and spindle-shaped melanoblasts containing variable amounts of fine brown pigments. Melanocytes and melanophages were also observed. Mitotic activity and pleomorphism were distinguishable (Fig.21).

\section{DISCUSSION}

The current study was carried out to clarify the different types of equine cutaneous neoplasms and to try to give a proportional percentage to each type according to the frequency of its occurrence. The obtained equine tumors were classified according to the clinical and histopathological bases into sarcoids, fibromas, vascular tumors, papilloma, squamous cell cacrcinoma and melanocytic tumors. 
Equine sarcoids represented the highest percentage (58.73\%) of the total examined specimens. High incidence of $35.3-90 \%$ was also recorded by Scott (1988). This variation could be attributed to many factors such as geographical location, the season of sample collection as the incidence of sarcoids affection increased in summer months. The results of the present study showed five types of sarcoids: fibroblastic, verrucous, mixed, occult and nodular. Other sarcoids classifications are done according to variable gross appearance verrucous (wart - like), fibroblastic (proud flesh - like), mixed (verrucous and fibroblastic) and occult (flat) (Scott, 1988). Another type of sarcoids is the malevolent sarcoids (Knottenbelt, et. al., 1995). One of the most diagnostic features for sarcoids is the rete peg formation which is attributed to the attenuated hair follicles at their origin often elongated and pointed (Scott and Miller, 2003). The proliferated fibroblasts were of spindle or fusiform shape with both vesicular or hyperchromatic nuclei according to the cell activity, while, the detected nuclear polymorphism was explained to be present in rapidly growing or recurrent tumors.

Fibromas in the present study were the next reported equine skin neoplasms that arise from the dermal and subcutaneous fibroblasts. The cause of these neoplasms is unknown, meanwhile, Jones, et. al. (1996) stated that fibromas in some species were caused by papiloma viruses. Microscopically, the current study described two types of fibromas in equine, the hard and the soft, according to the amount of fibrous material and the cell bodies in the tumor mass. Similar findings were recorded by Scott (1988).

Vascular tumors were considered to be benign neoplasms arising from the endothelium of blood vessels as reported by Hargis and McElwain (1984).

Microscopical examination of papillomas in the current study revealed typical features of full developed papiloma with epidermal hyperplasia, hyperkeratosis, acanthosis and hyperplasia of the basal cell layer. Campo (1977) and Scott (1988) found that papilloma in equine may be caused by DNA, Papova virus. This virus infects initially the basal keratinocytes of the basal cell layer followed by the stratum spinosum that leads to acanthosis and hyper and parakeratosis. The acidophilic cytoplasmic granules which were seen in the prickle cells were thought to be abnormal masses of keratohyaline material. Clusters of epidermal cells with vacuolated cytoplasm (ballooning degeneration) in the st. spinosum were previously explained to be virus - infected cells that had lost the tonofilaments and undergoing hydropic degeneration (Eyden, 1996). 
Concerning squamous cell carcinoma (SCC) in equine, the current survey recognized 3 cases with a percentage of $4.76 \%$. In this respect, Scott (1988) mentioned that SCC is a relatively common, locally invasive and occasionally metastatic neoplasm of most domestic species; sunlight is probably the most important carcinogenic stimulus for this tumor. Histopathologically, two pictures in the present study were recorded: the first pathological picture of well-differentiated SCC (two cases) and the second picture of anaplastic SCC (one case). The essential diagnostic criteria for diagnosis of SCC was the presence of polyhedral cells resembling those of stratum spinosum in the dermal side of the basal cell layer and basal lamina. Differentiation in SCC is in the direction of keratinization. These findings are in accordance with Roony and Robertson (1996) who found that keratin production and mitotic activity are highly variable and roughly proportioned to the degree of differentiation of SCC.

Melanocytic tumors in the current study were recognized at a percentage of $4.76 \%$. Other records considered melanomas among the most common neoplasms of equines. That could be attributed to unrecommended surgical removal of this type of tumor due to its high malignant behaviour. The development of grey coat coloration in older Arabian horse may result from the destruction of normal melanocytes on an auto-immuno or cytotoxic basis. Meanwhile, melanocytic tumors in aging horses were considered as a result of a disturbance in melanin transfer from dermal melanocytes to follicular cells. Melanomas in grey horses showed less malignancy, as grey horse has specific genetic factors inhibiting metastatic process (Seltenhammer et. al., 2003). Microscopically, the heavily pigmented laden melanocytes were explained to be due to the presence of type IV melanosomes which are fully melanized. Oval or rounded melanin pigment granules were formed due to abnormal pattern of melanin lay down as amorphous granular masses within melanosomes (Eyden, 1996).

From the present study it could be concluded that a variety of equine cutaneous neoplasms are observed with somewhat variable incidences. Sarcoids have the highest prevalence of occurrence with case history of husbandry intermixing with bovine. Therefore, to minimize the risk of sarcoids affection, animal's owner should avoid the husbandry intermixing between equines and bovines. Also, adequate and rapid medical management is recommended to any traumatic affection with therapeutic approach of sarcoids, especially after the surgical removal of the tumor to eradicate any dormant infectious agent. 


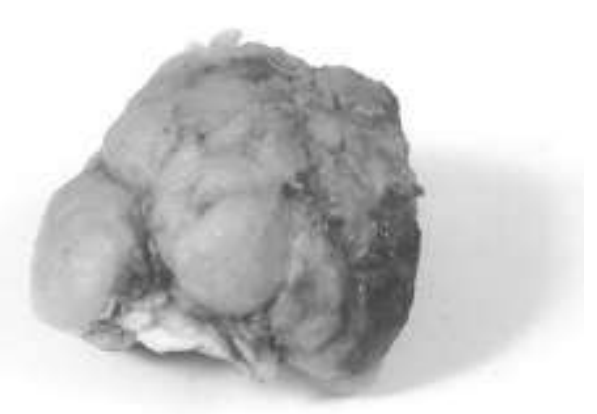

Fig. 1-a. Fibroblastic sarcoids showing complete ulceration of the epidermis with fleshy appearance.

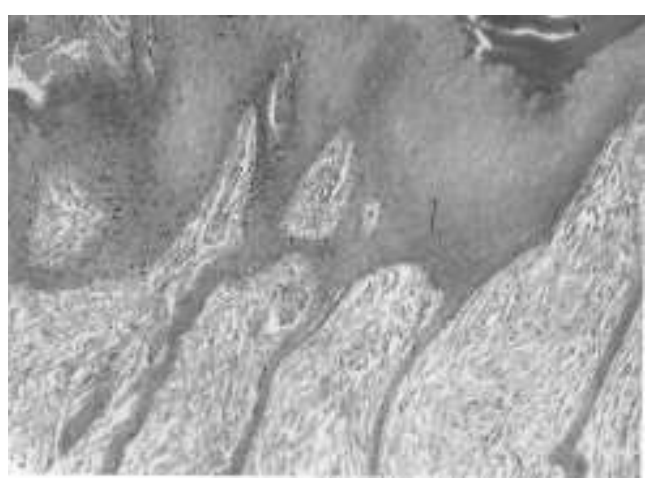

Fig. 2. Microscopic figure of the fibroblastic sarcoids revealing the basement membrane sent long thin rete pegs of pseudoepitheliomatous hyperplasia into the dermal layer with picket fence formation. H\&E X 200

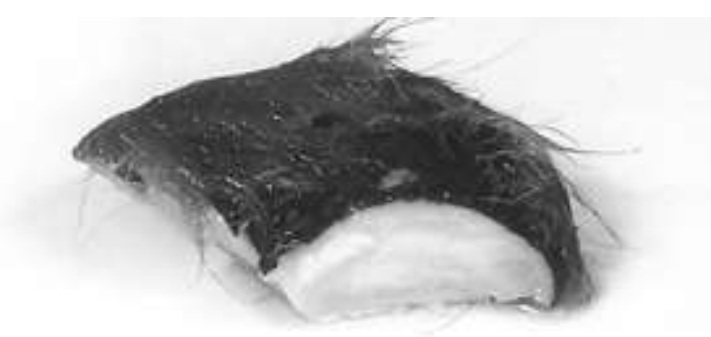

Fig. 1-b. Occult sarcoids appearing as localized thickening of the dermis under alopecic epidermis.

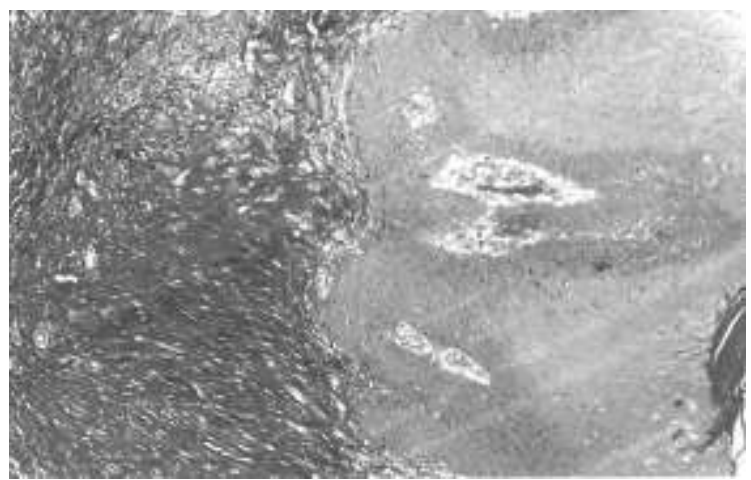

Fig. 3. Microscopic appearance of the fibroblastic sarcoids showing proliferation of the fibroblasts and collagen. Masson's trichrome X 200 


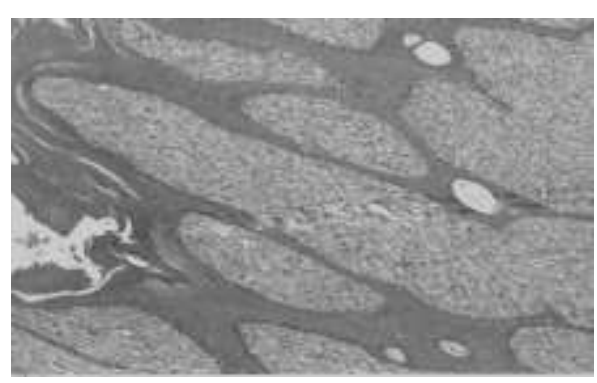

Fig. 4. Microscopic appearance of verucous sarcoids showing the perpendicular arrangement of the fibroblasts on the basement membrane forming 'picket fence'. H\&E X 200

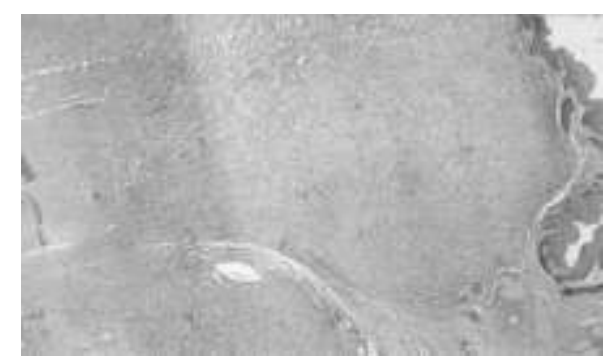

Fig. 6. Microscopic figure of the nodular sarcoids with no detcted 'picket fence' formation and unulcerated epidermis. Bundles of collagen fibers were detected in the deeper layer of dermis. H\&E $\mathrm{X} 100$

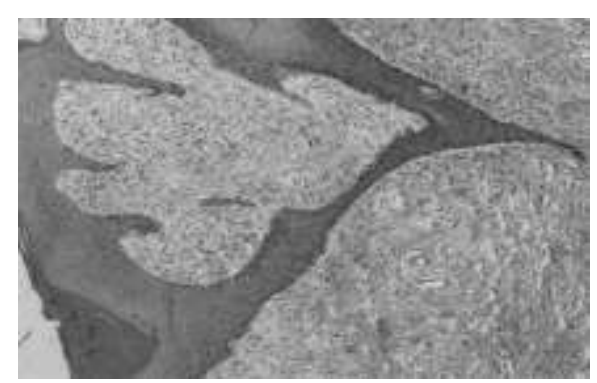

Fig. 5. Miroscopic figure of the mixed sarcoids demonstrating some parts of the epidermis sent very long thin rete pegs into the dermis with picket fence formation. H\&E X 20

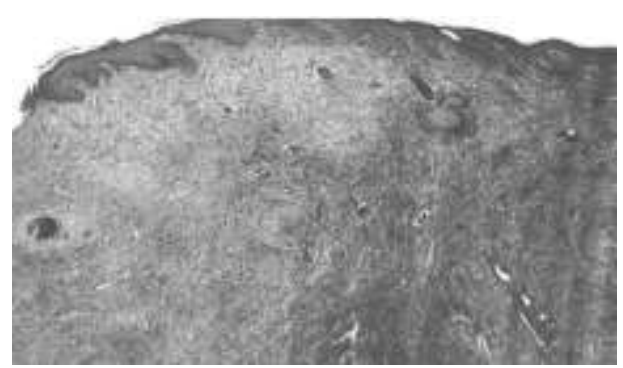

Fig. 7. Microscopic figure of the occult sarcoids showing mild to moderately hyperkeratotic epidermis followed by wavy arrangements of proliferated fibroblasts in the superficial dermal layer. H\&E X 100 


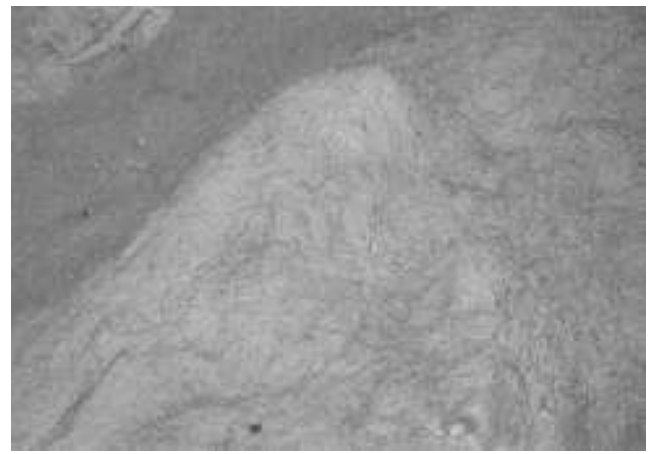

Fig. 8. Microscopic appearance of the soft fibroma revealing fibroblasts of spindle or fusiform shape, containing spindle - shaped or satellite and arranged in tight whorls or interlacing bundles, with few amounts of fine wavy arranged collagen bundles.H\&E X 100

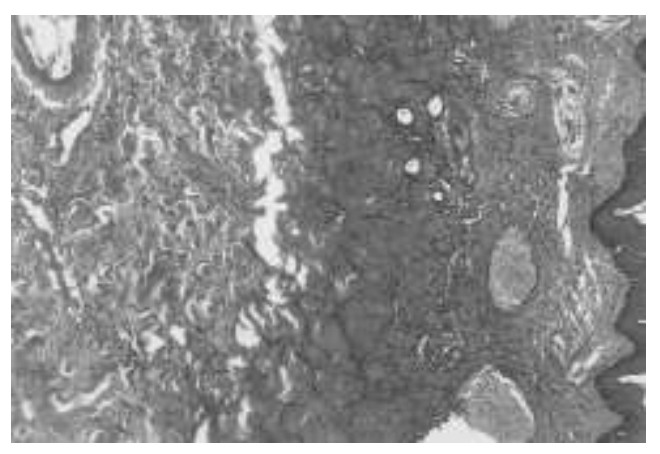

Fig. 9. Microscopic appearance of hard fibroma showing dermal layer diffusely infiltrated by numerous thick interwoven bands of collagen. H\&E X 200 


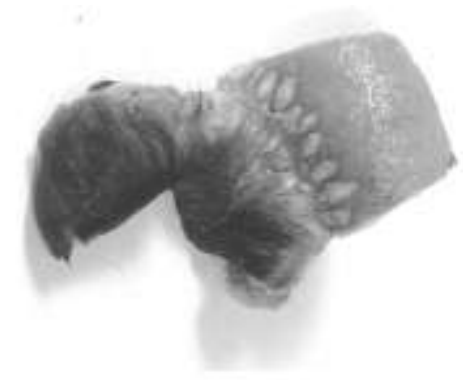

Fig.10. Gross appearance of the vascular tumor appearing as hard collagenous mass with horny papillae a the periphery.

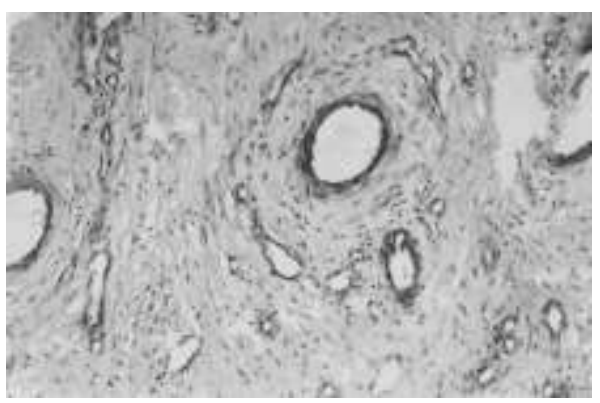

Fig. 11. Microscopic figure of the vascular tumor (capillary type) showing the vascular spaces lined by single layer of flattened endothelial cells with substantial number of pericytes concentrically arranged around. H\&E X200

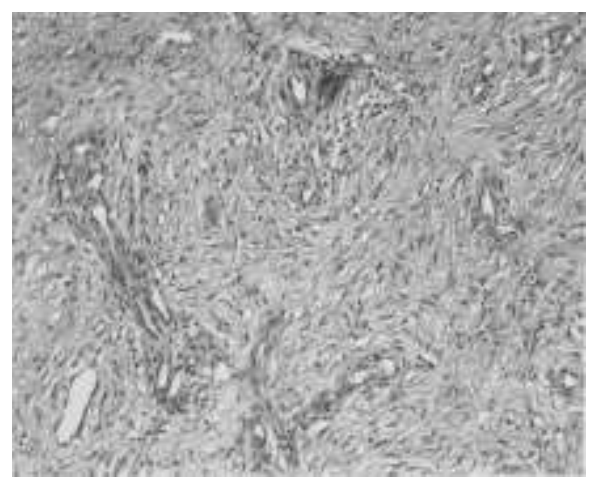

Fig.12. Microscopic figure of the vascular tumor (mixed type) showing the vascular channels supported by moderately thick collagenous septa. H\&E X 200 


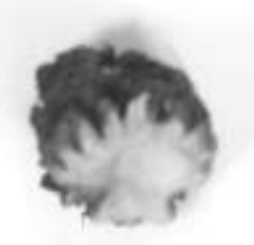

Fig.13. The gross appearance of the papilloma with finger-like projections.

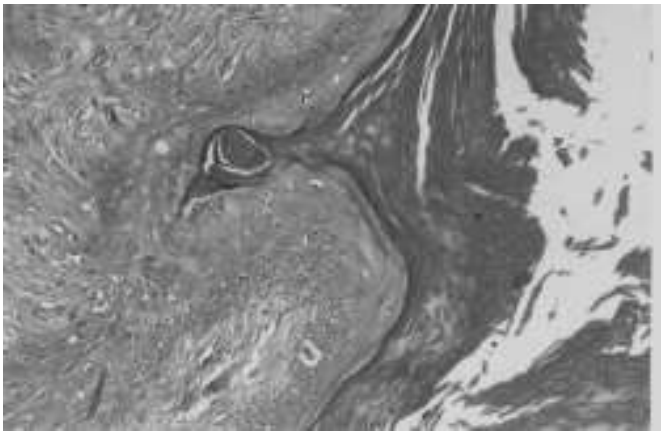

Fig. 14. Microscopic picture of the papilloma demonstrating marked hyperplasia with mitotic activity in the basal cell layer. H\&E X 200

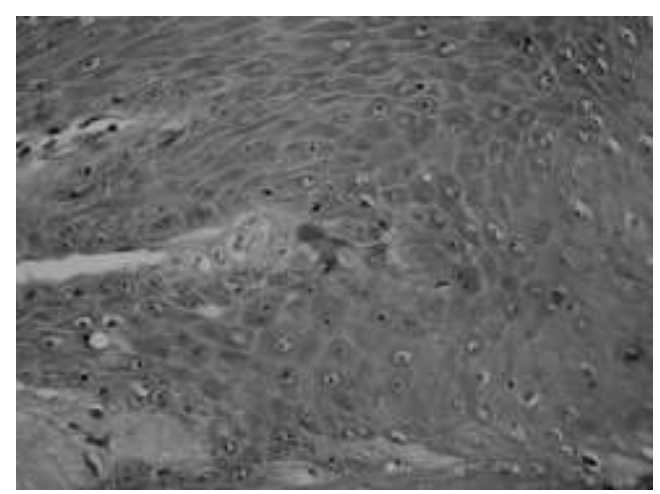

Fig. 15. Microscopic picture of the papillooma showing acidophilic cytoplasmic granules of abnormal keratohyaline material in some prickle cells. H\&E X 400 


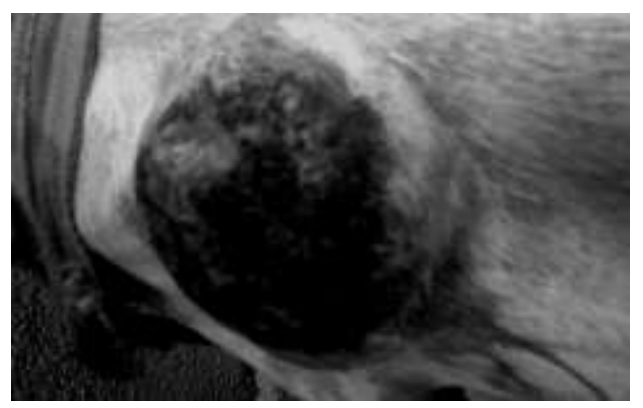

Fig.16. the gross appearance of the squamous cell carcinoma appeared as unhealed wound.

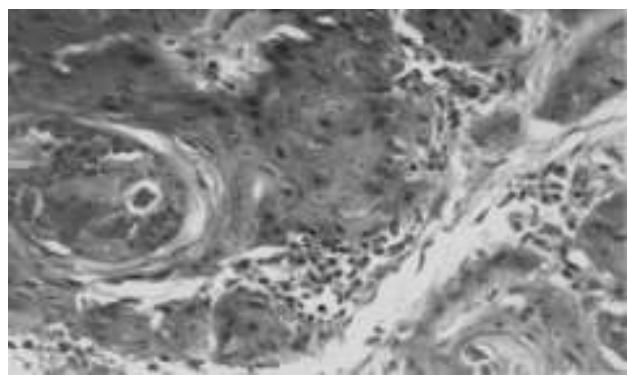

Fig.18. Microscopic figure of the SCC (anaplastic type) revealing malignant kerationcytes with frequent mitosis, the nuclei were pleomorphic and hyperchromatic. H\&E X 400

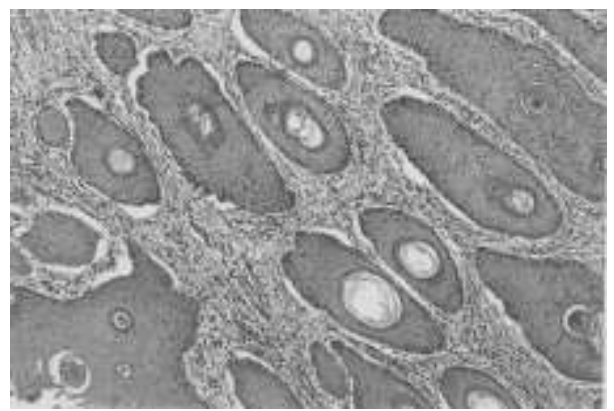

Fig.17. Microscopic figure of the SCC (well differentiated type) showing variable stages of bird nests formation, with multiple keratin whorls in the center of the nests, forming "pearls". H\&E X 200

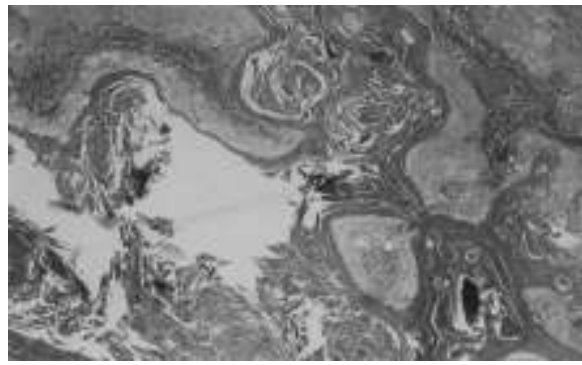

Fig.19. Microscopic figure of the SCC (anaplstic type) showing the nests containing highly eosinophilic laminated keratin in different stages of formation. H\&E X 100 


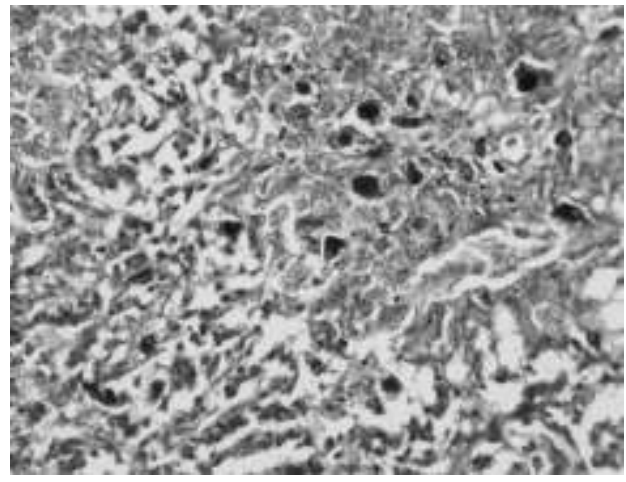

Fig. 20. Microscopic figure of the melanoma (dermal type) showing the melanin content masking the cytoplasmic and nuclear details. The cells represented a mixture of melanocytes and melanophages. H\&E X 400

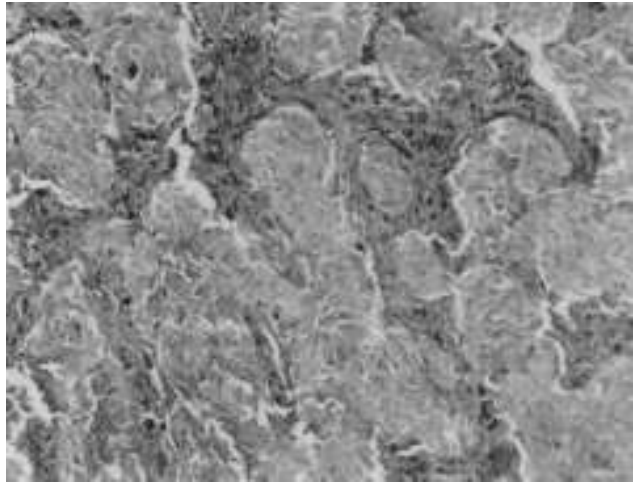

Fig.21. Microscopic figure of the malignant melanoma showing invasion of the deep dermal layer by sheets or nests of ovoid and spindle- shaped melanoblasts containing variable amount of fine brown pigment. $H \& E X 200$ 


\section{REFERENCES}

1. Bancroft, J. D. and A. Stevens. 1996. Theory and Practice of Histopathological Technique. $4^{\text {th }}$ Ed., Churchill, Livingston, Edinbourgh, London, Melbourne and New York.

2. Campo, M.S. 1977. Bovine papillomavirus and cancer. Vet. J., 154: 175-188.

3. Eyden, B. 1996. Organelles in Tumor Diagnosis: An Ultrastructural Atlas. Iowa State University Press, USA.

4. Goldschmidt, M. H. and M. J. Hendrick. 2002. Equine sarcoids. In : Tumors in Domestic Animals. 4th Ed. Metuen, D.J (ed.) : 88-89. Iowa State University Press, USA.

5. Hargis, A. M. and T. F. McElwain. 1984. Vascular neoplasia in the skin of horses. JAVMA, 184 (9) : 1121-1124.

6. Jones, T.C., R.D. Hunt and N.W. King. 1996. Veterinary Pathology. $5^{\text {th }}$ Ed. Bailliere Tindall, London.

7. Knottenbelt, D., S. Edward, and E. Daniel. 1995. Diagnosis and treatment of equine sarcoids. Practice, $17: 123-129$.

8. Martens, A., A. DeMoor, J. Demeulemeester and R. Ducatelle. 2000. Histopathological characteristics of five clinical types of equine sarcoids. Res. Vet. Sci., 69 : 295-300.

9. Ragland, W. H., G. H. Kewn and G. R. Spencer. 1970. Equine sarcoids. Equine Vet. J. 2: 2 - 11.

10. Rooney, J.R. and J.L Robertson. 1996. Equine Pathology. Iowa State University Press, USA.

11. Scott, D.W. 1988. Large Animal Dermatology. Neoplastic diseases, epithelial neoplasms. W.B. Saunders Company, USA.

12. Scott, D.W. and W.H. Miller. 2003. Equine Dermatology. W.B. Saunders Company, USA.

13. Seltenhammer, M.H., E. Heere-ress, S. Brandt, T. Druml, B. Jansen, H. Pehamberger and G.W. Niebauer. 2003. Comparative histopathology of greyhorse melanoma and human malignant melanoma. Pigment Cell Res., 17 (6) : 674-681. 


\title{
دراسات باثولوجية على بعض أنواع سرطانات الجلا بالعائلة الخيلية
}

\author{
'نجلاء محمد القلماوى' جيهان جميل شهاب' ،

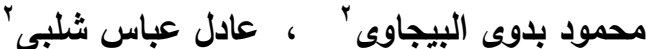 \\ 1 معهد بحوث صحة الحيوان - مركز البحوث الزراعية - وزارة الزراعة - الدقى - جيزة. \\ 2 كلبة الطب البيطرى- جامعة بنى سوبف.
}

أجريت هذه الدراسة لإلقاء الضوء على الأنواع المختلفة من سرطانات الجلد التى تصيب العائلة الخيلية. تم تجميع با حالة من سرطانات الجلد فى العائلة الخيلية من المناطق المختلفة بمصر وأجريت عليها الدراسات البانولوجية. أظهرت النتائج أن الورم شبه اللحمى هو أكثر أنواع سرطانات

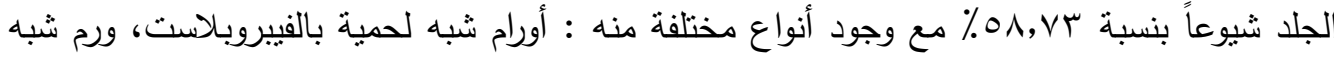
لحمى ثؤلولى، أورام شبه لحمية مختلطة، أورام شبه لحمية عقدية وأورام شبه لحمية مستترة. فى كل هذه هذه الأنواع كان التغير الجلدى العام هو زيادة تكاثر النسيج الليفى الضام لطبقة الأدمة.

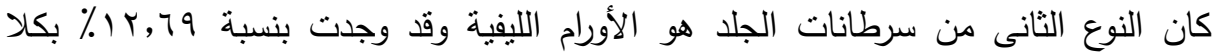
النوعين الصلب والرخو مع نكاثز النسيج الليفى الضام والذى كان فى صورة مرنبة نظامياً مع تكوين

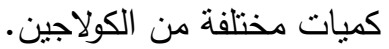
أما النوع الثالث من أورام الجلد فهو أورام الأوعية الدموية وقد وجد بنسبة عالية (1, (1) (1). أظهر الفحص الميكروسكوبى لهذه الأورام زيادة فى عدد الأوعية الدموية بأحجام وأثنكال مختلفة وقد نم تحديد نوعين من هذه الأورام هما الثعيرى والمختلط.

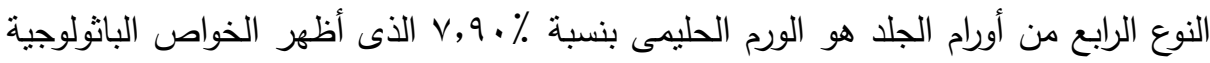
العامة فى صورة نتوآت بالجلد مع نمو نسيجى واضح وزيادة فى الكيراتينين.

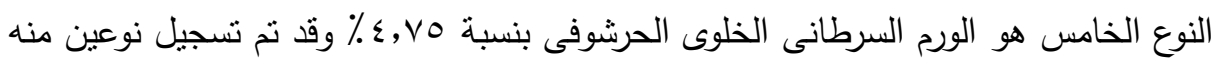
هما جيد التميز والثانى يحمل الخواص الإرتدادية رديئة التميز .

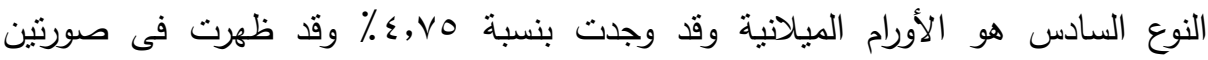

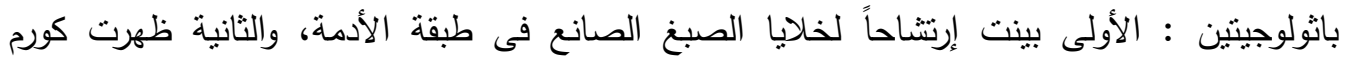
ميلانينى إرتدادى حيث وجدت تجمعات قليلة من خلايا الصبخ الصانع فى طبقة الأدمة السطحية.

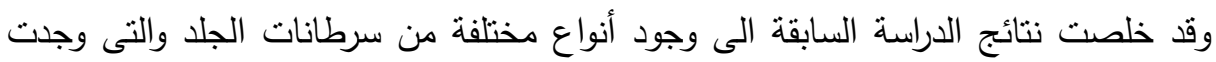

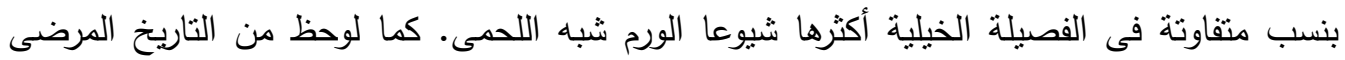

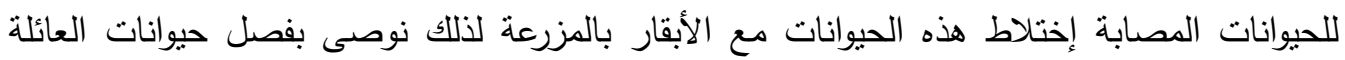

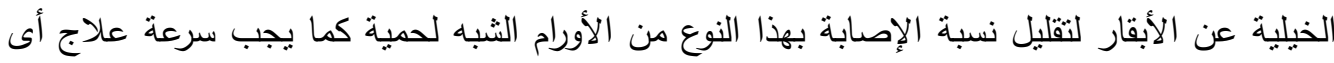
جروح أو كدمات موجودة بجلد الحيوان خاصة بعد إجراء العمليات الجراحية لإزالة هذا النوع من الأورام الجلدية لتجنب أى عدوى ميكروبية. 